\title{
The Role of Communication Climate in Improving Work Performance
}

\author{
${ }^{1}$ POPPY RULIANA, 2 PUJI LESTARI, ${ }^{3}$ SUSI ANDRINI, ${ }^{4}$ SUHENDRA ATMAJA \\ 134 Sekolah Tinggi Ilmu Komunikasi (STIKOM) InterStudi, \\ 2 Universitas Pembangunan Nasional "Veteran" Yogyakarta \\ email:1poppyruliana30@gmail.com; ${ }^{2}$ pujilestariupn@gmail.com; ${ }^{3}$ ussie69@gmail; ${ }^{4}$ prabusiliwangi1973@gmail.com
}

\begin{abstract}
Communication climate in an organization has a very important role because communication is a way for employees to interact, either with their superior or between departments in the same position or with other employees working in a different division to improve work performances. This research uses the theory of communication climate from Pace and Faules. The survey is used as a method in this descriptive research. The sample of study are 67 employees of Sari Ater Hotel \& Resort taken in random (probability sampling); data is collected by distributing questionnaires and interviews with employees from various levels existing in the Sari Ater \& Hotel Resort. The technique of data analysis carried out quantitatively using a formula of frequency distribution $n=f / n \times 100 \%$, and qualitatively by analyzing and interpreting the data. The research result shows that organizational communication climate practices play a significant role in improving the performance of Sari Ater \& Hotel Resort's employees.
\end{abstract}

Keyword: Organizational Communication, Communication Climate, Work Performance

\section{Introduction}

Communication is the process of exchanging messages between people involved in a work environment, as it expressed by Thomas I. Harries and Mark d. Nelson (2008:13): communication is one of the most dominant activities occurring in any work setting. The need to study, understand, and effectively use organizational communication has been, for many individuals, an after-the-fact enlightenment. The communication climate will facilitate an effective communication (that has to be done by the leader of organization) which regulates activities related to communication behavior of employees in carrying out their work. Research conducted by Yuningsih and Mulyana entitled Communication Pattern and Skill of the Leader in Private University Management (MIMBAR Journal, Volume 33, no. 1, 2017:172) states that the organizational communication pattern is a set of communication behaviors and rituals performed by all members of leaders to the lowest-level employees. While Littlejohn, Karen, and Oetzel, (2017:340) suggest that communication creates patterns and the structures provide a means to achieve organizational and individual goals.

Communication activities in Sari Ater Hotel and Resort consist of work interaction between departments and interaction and interdependence among employees through communication since it is the only way in which an influence of individual's behavior or employee takes place and create a good communication climate. Climate communications have an important role because it linked concepts, feelings, and hopes of the employees and help to explain the behavior of members' organization. One important aspect of organizing is the ability to communicate the roles, expectations, goals, and vision of the organization. However, according to Harries and Nelson (2008: 15) in their research results which stated that individuals' bad communication in a variety of work refers to the inability of others to communicate well, lack of listening skills shown by their peers, or the subordinates are a reluctance to follow the instructions. Sometimes, we all think that others failed to communicate and we almost puzzled on how other people did not hear us in a way

Received: October 19, 2017, Revision: April 03, 2018, Accepted: June 29, 2018

Print ISSN: 0215-8175; Online ISSN: 2303-2499. DOI: http://dx.doi.org/10.29313/mimbar.v34i1.3145.237-245

Accredited B based on the decree No.040/P/2014, valid on February, 18, 2014 until February, 18, 2019. Indexed by DOAJ, Sinta, IPI 
we meant it. For years, experts in the theory of management have emphasized the need to improve communication. Unfortunately, the awareness of the need to improve the communication does not always translate into understanding or how to use it better. A recent survey found that 40 hours in $14 \%$ of each workweek are wasted because of poor communication between staff and management, which is equal to a staggering amount of seven weeks of work productivity wasted per year. The transition to the knowledge, information, and technology that relies on an organization which posed by the digital era only underscores the growing importance of effective organizational communication climate.

Thus, it can be said that organizational communication climate is important as it affects the way we live, to whom we are talking, whom we like, how our feelings are, how we work, and the way we adapt with the organization (Ruliana, 2016: 138). However, how does the leader or manager of Sari Ater Hotel \& Resort know that he/she has set up a good communication climate that can improve the employees' performance? It will take a more in-depth study. Research conducted by General Electric ("Survey: GE, " 1984 in Harries and Nelson, 2008:17) to 10,000 employees found a relationship between good and direct communication of supervisoremployees and work satisfaction in the category of specific common issues, feedback, discussion of salaries, career counseling, and performance assessment. Other research by Abdussamad entitled The Influence of Communication Climate on the Employees - Performance at Government Agencies in Gorontalo City (An Indonesian Case Study) which published in Asia Pacific Journal of Multidisciplinary Research, vol. 3, no. 5, December 2015 Part I, revealed that there is a significant influence $(22.7 \%)$ of climate communication organization on performance of employees in institutions of industry, trade, cooperation, small and medium enterprises and investment in Gorontalo city.

\section{Methodology}

The approach used in this research is quantitative. The method used in this descriptive research surveys on the role of organizational communication climate in improving employees' performance of Sari Ater \& Hotel Resort. This method is suitable because it presents a further stage of observation. Once you have such a set of classification schemes, investigators then measure the magnitude or distribution of the properties among members of a particular group. In this case, statistical techniques such as frequency distribution (Meyer and Greenwood, in Silalahi, 2009: 26) appears on the role of organizational communication climate in improving employees' performance using the concept, theory and approach that fit the problem and research objectives since descriptive study demands a higher and ideal capability of research compared to explanation research which demands the same high standards (Cooper and Emory, in Silalahi, 2009: 30).

The purpose of this research is to find out and analyze the importance of organizational communication climate practice in improving the performance of employees of Sari Ater \& Hotel Resort. The population in this study is 672 employees from Sari Ater Hotel \& Resort. To determine the sample size, the researchers took $10 \%$ of the total population and obtained 67 employees as respondents by using probability sampling. Data collection techniques used are interviews and a questionnaire distributed to all selected respondents. The data were analyzed quantitatively by using frequency distribution formula i.e. $n=f / n \times 100 \%$ (Arikunto, s. (2002), and qualitatively by indepth analyzing and interpreting.

\section{Dimensions of Organizational Com- munication Climate and Employees' Performance}

Dimensions of organizational communication climate according to Pace and Faules in their book of Organizational Communication, Strategy to Improve Company's performance (2006: 159-160).

Trust. Personnel at all levels should strive to develop and maintain a relationship filled with trust, confidence, and credibility which is supported by statements and actions. The leaders should put their efforts to form a trust between the sender and the recipient of the message. The trust will lead to open communication that will facilitate the necessary approval between subordinates and superiors.

Joint decision making. Employees at all levels in the organization should communicate and consult on all issues in all areas of the organization's policies which 
relevant to their position. Employees at all levels must be given the opportunity to communicate and consult with superior management in order to participate in the process of making decisions and goal setting.

Honesty. The general atmosphere suffused with honesty and candor should coloring the relationships within the organization, and the employees are able to say "what is in their mind" without regarding whether they talk to a friend, colleague, or superiors.

Openness in downward communication. Down communication shows the flow of messages from superiors or leaders to subordinates.

Listening in upward communication. Listening in upward communication is a message flows from subordinates to superiors or from lower level to higher level. The purpose of this communication is to give feedback, suggestions and ask questions.

The most prevalent activities being valued in an organization and have an effect on the process of organizational communication is the performance of employees (Pace and Faules, 2006:134), in which how they do everything that is associated with a job, position, or role in the organization. Two types of behaviors or job duties comprise of important elements of job performance are: functional tasks relating to how well an employee completing all his/her work including the technical aspects of the activity, and behavioral tasks regarding on how well employees respond to interpersonal activity with other members of the organization including addressing conflicts, time management, empowering others, working in groups, and work independently. Hasibuan (2003:94) stated that the performance is a result of work achieved by a person in carrying out the duties charged to him/her based on skills, experience, and determination.

\section{The Effects Of Organizational Communication Climate}

Communication climate is different from organizational climate within a climate of communication that involves the perception of messages and events related to message occurred in the organization. The organizational communication climate is a function of how activities occurred in organization demonstrate to its members that organization trust them and allow them to take risks; support them and give them responsibility in doing their job; openly provide accurate and sufficient information about the organization; an alternative to listen to and get information that is trustworthy and honest from member organizations; actively consulted with members of the organization to see that their involvement influence organization's decisions; and have a concern for high standards and challenging work (Redding, in Ruliana, 2016). Members of an organization determine and confirm the existence of the communication effect. Thus, through the interactive process, members' organization verify the existence of support, trust, openness, and honesty. Therefore, the effect of communication can vary and change according to the way in which they are defined and confirmed through the interaction between members of the organization.

\section{Profile of Sari Ater Hotel \& Resort's Employees}

Employees' profile is intended to find out the identity of employees of Sari Ater Hotel and Resort and relate it to the research purpose so that in-depth analysis or interpretation of research results data can be obtained. A questionnaire distributed to all respondents in all departments in Sari Ater \& Hotel Resort randomly. Data finding as the result of research on the role of communication climate in improving the employees' performance of Sari Ater Hotel \& Resort is shown in table 1.

Generally, the profile of Sari Ater Hotel \& Resort is dominated by a male with 57 employees $(85 \%)$, age ranges from $30-$ $39(40 \%$,$) up to 40-49$ years. If the range is added, there will be more than $50 \%$ of productive age categories, which is in accordance with Number of Dependency stating the comparison between unproductive age population (below 15 years and over 65 years) and productive age (from 15 to 64 years) multiplied by 100 (BPS / Central Bureau of Statistics, 2016). For the educational level, in general, employees are high school graduates. It surely needs improvement and they should be given the opportunity to continue their education to a higher one since the development of tourism and hospitality industry businesses are increasingly competitive. The management of Sari Ater Hotel \& Resort need to pay attention to this matter because the level of education 
Table 1

Profile of Employees of Sari Ater \& Hotel Resort

\begin{tabular}{|c|c|c|c|c|c|}
\hline No & & Respondent's Answers & $f$ & $\%$ & Total \\
\hline 1 & Gender & $\begin{array}{l}\text { a. Male } \\
\text { b. Female }\end{array}$ & $\begin{array}{l}57 \\
10\end{array}$ & $\begin{array}{l}85 \% \\
15 \%\end{array}$ & 100 \\
\hline 2 & Age & $\begin{array}{l}20 \text { to } 30 \\
31 \text { to } 39 \\
40 \text { to } 49 \\
>50\end{array}$ & $\begin{array}{c}18 \\
26 \\
19 \\
2\end{array}$ & $\begin{array}{c}28 \% \\
40 \% \\
29 \% \\
3 \%\end{array}$ & 100 \\
\hline 3 & Education & $\begin{array}{l}\text { Elementary } \\
\text { Junior High School } \\
\text { Senior High School } \\
1 \text { Year Diploma } \\
3 \text { Years Diploma } \\
\text { Bachelor } \\
\text { Magister }\end{array}$ & $\begin{array}{c}2 \\
1 \\
37 \\
1 \\
12 \\
12 \\
1\end{array}$ & $\begin{array}{c}3 \% \\
2 \% \\
56 \% \\
2 \% \\
18 \% \\
18 \% \\
2 \%\end{array}$ & 100 \\
\hline 4 & Length of Work & $\begin{array}{l}0 \text { to } 5 \\
6 \text { to } 9 \\
10 \text { to } 15 \\
16 \text { to } 20 \\
>21\end{array}$ & $\begin{array}{c}21 \\
15 \\
12 \\
8 \\
9\end{array}$ & $\begin{array}{l}38 \% \\
23 \% \\
18 \% \\
12 \% \\
14 \%\end{array}$ & 100 \\
\hline
\end{tabular}

in organizational communication climate is one of the essential elements for the process of transferring the messages or information relating to work planning or execution from the superiors to the subordinates (vertical communication) or subordinates to subordinates (diagonal communication), and also in conducting a formal or informal cross-communication. The importance of educational level lies in how employees can receive and understand the content of the message delivered by the superiors and how they interpret the work they have to perform. Therefore, the leaders/superiors will choose the right person for the right job according to their communication competence to avoid miss communication. For the length of work, there are 21 persons (35\%) have been working for $0-5$ years and only 9 people (14\%) have been working for more than 20 years. Their long duration of work is equal to their high loyalty for the company and shared a great contribution to the organizational development of Sari Ater \& Resort Hotel.

\section{Organizational Communication Climate of Sari Ater \& Hotel Resort}

The term of climate here is an allusion (metaphor). The metaphor is a form of speech in which a term or a phrase with obvious means is being applied to different situations with the intention of declaring a resemblance. According to Sackmann (in Pace and Faules, 2006:147) climate is an allusion that can give a clear picture on the level of cognitive, emotional, behavioral, and states a certain part on the action without specifying the actual behavior. The climate of communication and organization has a very important role because it relates concepts, feelings, and hopes of organization's members and helps explain the behavior of the members of the organization. Generally, the concept of "climate" is one of the richest constructions in the theory of organization, and specifically, the organizational communication (Falcione, Sussman, and Herden, 1987, p. 195). Relating to this, Redding (in Ruliana, 2014: 138-139) states that the organizational communication climate is far more important than skills or techniques of communications solely in creating an effective organization. One of the reasons why communication climate plays an important role is because it has the capability to understand better factors that encourage employees to behave in certain ways and bridge the practices of human resources management and productivity.

Furthermore, organizational communication climate according to Pace and Faules (2006: 147) is a macro image, abstract and a combination of a global phenomenon called organizational communications. We assume that climate evolves from the interaction between organizational characteristics and individual perception over those characteristics. The climate is seen as a quality of subjective experience from the 
perceptions of characters that tend to be relatively immutable in the organization.

Organizational communication climate in improving the performance of employees of Sari Ater \& Hotel Resort is can be seen from the dimensions of trust, joint decision making, honesty, openness in downward communication, listening in upward communication, and attention to high performance goals (Pace and Faules, 2006; and Ruliana, 2016) as shown in Table 2.

Communication climate practice in improving the performance of employees of Sari Ater Hotel \& Resort can be analyzed and interpreted as follows:

\section{Trust}

High trust of subordinates/employees towards superiors is actually determined by communication style of leadership and communication climate built by the leaders of Sari Ater organization, meaning that the level of trust given by subordinate highly depends on the openness of management in accepting personally the employee who will do the communication which usually done face to face and interpersonal communication process wherein message delivered by subordinates and obtain an immediate response. Most of the employees $(65 \%)$ said it was an actual condition of the organization, where the level of trust and honesty of the leaders in managing the communication is effective. It means that subordinates have a high trust in their superiors, in other words, that a subordinate can do the following: first, they can talk about their work, achievements, progress, and plans for the future; second, they can share problems of work that have not been solved yet and may require some help; third, they can give suggestions or ideas for improvement in their units or in the organization, and reveal how subordinate thoughts and feelings about their work, colleagues, and organization.

The above description illustrates the process of downward communication at Sari Ater \& Hotel Resort which tells that information flows from higher level authority to the lower one, while upward communication is vice versa. Information from management to employees can be seen in the structure of communication of Sari Ater Hotel \& Resort which build trust and honesty as certainly expected by employees so that their work would get good appreciation from their superiors. Vocal point in organizational communication is often moving towards employees' communication with main attention to downward communication, carrying information through the group of management and operational. Communication channels used by the leaders are a letter of the decree, memo, phone, meetings, periodical reports, presentations, and e-mail.

\section{Joint Decision Making}

Communication climate is quite important in the process of decision making in an organization to build an effective system of communication, especially in establishing good relationships (human relations) among various departments in charge of creating openness or space communication to achieve organization's objectives in accordance with its vision and mission. Decisions taken by a leader who acts as a communicator will certainly be discussed first with all employees or communicants involved in the work so that they could provide inputs which contribute to the development of the company.

Joint decision making shows a high percentage of $40 \%$ where employees stating the description of condition in the organization is half true and half wrong - so employees at all levels should communicate and consult all issues in all areas of organization>s policy relevant to their position. Employees at all levels should be given a way to communicate and do a consultation with the management level above them for the purpose of participating in decision-making and goalsetting process. The finding indicates that the high-performance organization applies higher levels of participation which established through the levels of trust, support, a higher listening skill in communication, and openness in downward communication.

Leaders have been given a space of communication for the benefit of the organization, or it can be said that internally the organization has applied the open communication system to allow employees to communicate at any time they want to suit their needs regarding the work and improving their performance. Communication space can be assumed as showing the actual situation of information flow in organizations where employees can be motivated to communicate directly with the supervisor to discuss their tasks and responsibilities. In addition, the communication space can also 
be done informally depending on the time or context and purpose of communication from subordinates in a form of either giving suggestions or proposals to the superiors. The same thing also happens when superiors give assignments or instruction to subordinates.

\section{Honesty}

Honesty shows a high percentage of $44 \%$ which tells the conditions inside the organization that has more truths than falses. This reflects an atmosphere of honesty that has to include relationships within the organization where employees can say whatever on their minds or what they want to address regardless of whether they are talking with peers, subordinates, or superiors. Such condition shows more of interpersonal relationships or communication between leaders and employees in all levels of the organization and can be conducted in formal/informal and direct way, for example the discussion or meeting to deliberate work program on progress or other programs that will be carried out by each division through interpersonal group communication which enable members to find out the response or feedback immediately from employees or superiors (top executives). There is also indirect communication using tools or specific media, such as memo and letter of assignment, which are very contextual. Communication between leaders and lower level workers (the staffs) is conducted informally and called Cross Communication or Diagonal Communication which can motivate the staffs to show their best performances. The research findings indicate that support communication is achieved by informing and educating employees at all levels in an organization's strategy and being motivated to support the strategy and objectives of performance.

\section{Openness in Downward Communication}

Other description about Sari Ater Hotel \& Resort which state that all personnel received information that enhances their ability to coordinate with other personnel or division and information related to the company, its organization, its leaders, and the plans are taken as partly right and partly false by most employees $(40 \%)$ who shared the conditions in the organization. $19 \%$ of the employees stated that the condition of the organization has more of the truth than the false, and only $19 \%$ told that the actual description reflected the direction of the flow of information as it was already expressed earlier in which who is talking to whom have big consequences in the functioning of an organization. The one who speaks is certainly the leader/superior of Sari Ater Hotel Resort who has the higher authority act as a communicator or a source of information and distribute/provide that information/instructions to subordinates (middle manager) who do the work. Instructions from the superior may need to be implemented simultaneously, sequentially, or both combined. However, information flow direction does not represent the truth of the organization's condition, which means there are only certain groups receive information from the leader and almost all employees are lacking it. That statement reflects the existence of horizontal communication in a form of delivering information among fellow colleagues in the same work unit. A work unit consists of individuals placed on the same level of authority in the organization and has the same leader. Sari Ater Hotel \& Resort work units have departments or divisions led by an employee. The communication occurs between one department and others with higher authority is called cross-channel communication, in which information is given beyond functional or work unit boundaries, and takes place among people who have no subordinate-superior relationship.

The flow information direction above describes the occurrence of pattern or the opposite of communication network where wheel pattern and circle pattern are restricted by the organization. Wheel pattern is a pattern that directs all information to individuals with central position. People in a central position receive contacts and information provided by members of other organizations and solve problems by the advice and consent of other members. Circle pattern allows all members to communicate with each other only through a kind of message system repetition. There is no single member has a direct contact with other members, and there is no member has a direct access to all information needed to solve the problems.

Based on those two patterns of information and the results of field research, the researchers conclude that the pattern used by Sari Ater and Hotel Resort is the wheel pattern where the flow of information is very concentrated - in the overall of members' accessibility between one and the other, moral 
and satisfaction toward the process, number of messages being sent, and the ability to adapt the task changes. On the other side, wheel pattern allows a better control over the flow of messages, a leader that arise faster with a more stable organization, and a high accuracy of problem-solving, but it seems that pattern has overload messages and jobs. Interpersonal role as a leader who decides on something (decisional role) is very important because it is the basic source of information for decision-makers. One thing clear is that the leader of employees holds a very important role in the system of decision making in the organization. In its formal authority, a leader can perform new and important activities; in his/her position of the formal "nerve center", he/she obtains a complete and actual information to make a decision that determines the organization's strategy.

\section{Listening in Upward Communication}

Information received from subordinates either a proposal or suggestion can be expressed directly or indirectly and could possibly address in a formal setting such as a morning briefing where employees can share their ideas for the development of the organization. Sari Ater Hotel \& Resort's employee's statements showed that $36 \%$ of them described the organization's condition as partly true and partly wrong. It reveals that the leader (supervisor) has a lack of trust for the information received or another possibility is that he/she has filtered the information received in advance and then give a response to it. This condition can be caused by several reasons, namely: (1) the tendency of employees to conceal their thoughts; (2) the assumption that the leader and employees are not interested in employees' problems; (3) the lack of appreciation for upward communication from employees; (4) the assumption that the leader and employees could not be reached and give no response to employees' statements. $27 \%$ of employees described the condition that has more of the truth than false. It indicates that upward communications are important for several reasons: (1) the flow of information to the top is valuable for the decision making by those who manage the organization and supervise the activities; (2) communication to top management to inform when the subordinates are ready to receive information from them and how good they accept that information;
(3) upward communication allows or even encourage all the complaints and grievance to come forth so that the leader knows problems in actual operations which bothering the employees; (4) upward communication fosters appreciation and loyalty to the organization by giving opportunities to employees to ask questions and contribute ideas and suggestions concerning the operation of the organization; (5) upward communication aids the leader to determine whether the subordinate understands what is expected of the downward flow of information; (6) upward communication helps the employees to overcome their work problems and strengthen their involvement in work and organization.

Therefore, it can be said that upward communication performed by subordinates is seen very important by top management or employees because those who know the real and actual condition on the field are operational executors, such as public relation officers, sales marketing, and others related to job competency.

\section{Attention to High-Performance Objectives}

A high percentage of $50 \%$ represents the actual condition of the organization. Employees at all levels in the organization must demonstrate a commitment to highperformance objectives -high productivity, high quality, low cost- and high attention to members of other organizations. A serious attention from the leader towards the wellbeing of all personnel or employees would definitely take a coordination between the leader of management with human resources employees. It is a task of human resources employees to create such condition which will motivate the employees. However, in the reference point of assessment, there are three types of different achievement gauge criteria. The first one is performance measurement based on results: this type of achievement criteria formulates work based on the achievement of the organization's objectives, or an end result measurement. Second is performance measurement based on behavior which measures the means of target achievement and not the end result. That type of criteria is usually known as BARS (Behaviorally Anchored Rating Scales), made of "critical incidents" related to the various dimensions of performance. Third is performance measurement based on "judgement" as a type of performance 
criteria which measure the achievement according to particular behavior description (specific) i.e. the amount produced (quantity of work), the extent of job knowledge (job knowledge), the willingness to do the job (cooperation), personality and leadership (qualities of personnel). In addition, an important emphasis in creating a climate of good communication is to apply a transparent and clear organizational culture and the importance of implementing good human relations between the leader and employees as well as putting public relations officer as gatekeeper between the interests of organization's leader and employees through the coordination with Human Resources Development (HRD) in order to be able to accommodate all aspirations of need and wants from all divisions of the organization.

This dimension is the output of trust level, support, and more openness in communication. Finding of this indicator is the employees work motivation which shows a positive role towards their performance. Further analysis shows that higher attention to high performance can be applied if employees receive qualified information related tasks and support perceived from superiors, peers, and subordinates.

Based on the discussion about the Role of Organizational Communication Climate in Improving Work Performance of Sari Ater Hotel \& Resort's Employees which has been elaborated above, then the total or overall score on whether organizational communication has already played a significant role or has not can be seen in figure 1 .

\section{Good}

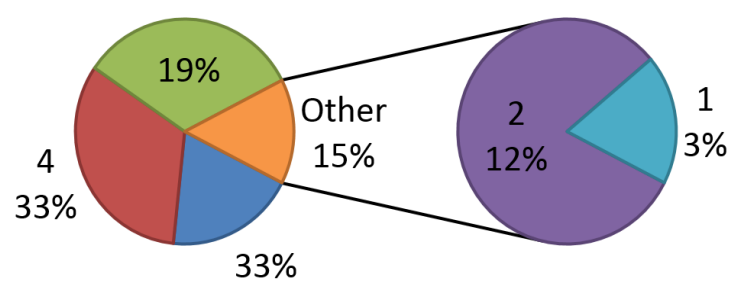

Figure 1

The Total Calculation Result of the Role of Organizational Communication Climate in Improving Work Performance

From the calculation of total score, clusters or areas which successfully implementing the organizational communication climate in Sari Ater Hotel \& Resort are formed with the support of various indicators, and it can be said that the role of organizational communication climate in Sari Ater Hotel \& Resort is good $(33 \%)$ in improving the performance of employees.

\section{Conclusion}

Based on results of research and discussion above, it can be concluded that the communication climate occurred in Sari Ater Hotel \& Resort have a significant role in improving the work performance. Dimensions of trust, joint decision making, honesty, openness in downward communication, listening in communication and attention to high-performance objectives are fundamental elements in the organization. The implementation is executed in accordance with the vision and mission that has been established by the company before. In addition, communication climate is important since it links the concepts, feelings, and expectations of members' organization or the employees; it helps to explain the behavior of members of organization and able to better understand of what element encourage the employees to behave in certain ways. In general, the information flow management and interpersonal quality relationships are viewed as a source of power that allows employees to have a broader perspective and allows the organization to effectively coordinate and work together.

It may be suggested from the theoretical discussion that an individual who has a high motivation will feel the communication climate of an organization as a more open and ideal. The ideal communication climate consisting of positive response towards the dimensions of communication generated from research findings. In other words, the more supportive environment for communications -more people participate in decision-making, having trust and confidence in their superiors, subordinates, and peers; being open, and understand the objectives of the organizationthere will be more likely a positive collective attitude in communications climate.

\section{References}

Arikunto, S. (2002). Prosedur penelitian: suatu pendekatan praktis. Jakarta: Rineka Cipta.

Badan Pusat Statistik 2016, https://www.bps. 
go.id/istilah/index.html? Istilah_page $=4$

Falcione, R.L., Sussman, L., dan Herden, R. P. (1987). "Communication climate in organizations, Handbook of Organizational Communication: An Interdisciplinary Perspective", California: Sage, Newbury Park.

Littlejohn W. Stephen, Karen A.Foss, John G.Oetzel, (2017). Theories of Human Communication, Eleventh Edition, Illinois: Waveland Press, Inc

Harries L.Thomas dan Mark D. Nelson.(2008), Applied Organizational Communication, Theory and Practice in A Global Environment, Third Edition, New York: Lawrence Erlbaum Associates.

Hasibuan Malayu, (2003), Organisasi Dan Motivasi Dasar Peningkatan Produktifitas. Bumi Aksara. Jakarta

Pace, R. Wayne, Faulers, Don F. (2006). Komunikasi Organisasi. Strategi meningkatkan Kinerja Perusahaan. Remaja Rosdakarya editor Dedi Mulyana: Bandung

Ruliana, Poppy, (2016). Komunikasi Organisasi, Teori \& Studi Kasus. Edisi Kedua, Jakarta: Raja Grafindo

Silalahi, Ulber, (2009). Metode Penelitian Sosial, Bandung: PT Refika Adhitama

Yuningsih, A. dan Mulyana, D. (2017). Communication Pattern and Skill of Leaders in Private

University Management, Jurnal Mimbar, Volume 33, No 1, 2017: 167-172)

Zuchri Abdussamad. (2015). The Influence of Communication Climate on the Employees' Performance at Government Agencies in Gorontalo City (An Indonesian Case Study) yang dimuat dalam Asia Pacific Journal of Multidisciplinary Research, Vol. 3, No. 5, December 2015 Part I 